\title{
Normative values of vestibulo-ocular reflex gain obtained through Video Head Impulse Test: an integrative literature review
}

Patricia Oyarzún Díaz ${ }^{1}$ https://orcid.org/0000-0002-1452-6447

Sebastián Rivera Retamal ${ }^{1}$ https://orcid.org/0000-0003-1823-0229

Sergio Jiménez Cofré https://orcid.org/0000-0001-8537-3145

Hugo Segura Pujol ${ }^{1}$ https://orcid.org/0000-0002-3970-0114

Universidad Santo Tomás, Facultad de Salud, Escuela de Fonoaudiología, Talca, Chile.

Research support source: This study was financed by the Fondo Interno de Investigación de Clínicas Docentes año 2019 (código TAS 0000040215/ERP 11600001), of the Universidad Santo Tomás, Chile.

Conflict of interests: Nonexistent

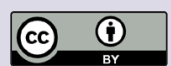

Received on: April 20, 2020

Accepted on: August 11, 2020

Corresponding address:

Patricia Alejandra Oyarzún Díaz

Circunvalación Poniente 1855 Talca

Edificio Car 3

3460000, Talca, Chile

E-mail: patriciaoyarzundi@santotomas.cl

\section{ABSTRACT}

Purpose: to identify and analyze the available evidence on the reference values of the vestibulo-ocular reflex gain obtained with the video head impulse test.

Methods: an integrative review based on the PRISMA protocol, searching the ProQuest, EBSCO, PubMed, ScienceDirect, Cochrane Library, LILACS, and SciELO databases with keywords. The studies included were original research articles, systematic reviews, and meta-analyses published since 2009, involving humans, written in English, Spanish and/or Portuguese.

Results: 10,250 studies related to the keywords were found. Of these, 10 articles met the inclusion criteria and were analyzed following the CADE protocol. On the horizontal plane, the values ranged from 0.80 to 1.06 , while on the right anterior/left posterior and on the left anterior/right posterior planes, the values ranged from 0.80 to 1.03. Other relevant data for obtaining the gain were analyzed, such as the number of impulses, the assessor's experience, the patient-object distance, and the percentage of asymmetry.

Conclusion: little research on the theme, recently developed and published, mostly in European countries, was found. This shows the need for a greater number of studies to strengthen the scientific evidence.

Keywords: Reference Values; Vestibular Function Tests; Vestibular Nerve 


\section{INTRODUCTION}

Balance results from integrating the sensory input of visual, vestibular, and proprioceptive systems, mediated by the central nervous system ${ }^{1}$. The vestibular system comprises the otolithic organs (utricle and saccule) and the semicircular canals (anterior, posterior, and lateral), which function respectively as linear and angular accelerometers ${ }^{2}$. The information coming from these structures, once having reached the brainstem by way of the vestibular nerve, establishes various pathways to make connections with multiple systems ${ }^{3}$. Hence, quick reflexes are generated, which are useful for standing, head stability in space, and visual stability ${ }^{4}$. These are the vestibulospinal, vestibulocollic, and vestibulo-ocular reflexes.

Specifically, the vestibulo-ocular reflex (VOR) enables the images to stabilize on the retina when the head moves, moving the eye in the opposite direction to that of the head to keep the image in the center of the visual field ${ }^{5}$. Traditionally, the peripheral vestibular organs that participate in the VOR have been studied with the caloric test, which was first described by Bárány in $1906^{6}$. Although this procedure is still in use nowadays, it is a test that only allows for the study of the lateral semicircular canal (SCC). Moreover, it is poorly tolerated by some people when dealing with a nonphysiologic stimulus, causing an intense nauseating reflex ${ }^{1}$. Another relevant difference is the stimulation speed generated by the caloric test and by the VHIT. The first one generates a low-frequency stimulation $(0.003 \mathrm{~Hz})$, while the vHIT generates a physiological stimulation closer to everyday situations - i.e., high-frequency ones $(2-5 \mathrm{~Hz})^{7}$. The scleral search coil technique, designed by Robinson in 1963, has been considered the gold standard to assess $\mathrm{VOR}^{8}$. However, despite its usefulness, it is an expensive, uncomfortable, and invasive procedure for the patient, and of difficult clinical implementation ${ }^{9}$, besides being a lengthy performance with complex interpretation ${ }^{10}$.

In 2005, Ulmer and Chays ${ }^{11}$ reported using a camera placed in front of the patient to record and register the eye movement in the head impulse test. The purpose was to quantify the function of each SCC. Later, MacDougall, Weber, McGarvie, Halmagyi and Curthoys $(2009)^{12}$ described in detail the procedure currently most used. The vHIT results from the need for a new complementary examination that overcomes the disadvantages of the previous ones ${ }^{13}$ and that makes it possible to evaluate the efficiency of the VOR in a simple, objective, and easy performance, without causing discomfort to the patient ${ }^{14}$. Also, it evaluates individually the function of the six $\mathrm{SCC}^{15}$, and thus, the function of the superior and inferior vestibular nerves ${ }^{16}$.

The VHIT is based on the record of the eye movements with high-speed cameras (250\%/seg) placed in goggles adjustable for each patient. By means of a passive, unpredictable, and fast head movement, it makes it possible to determine the efficiency of the VOR, which is the "property of generating slow eye movements almost perfectly compensatory in direction and speed to the head movements" 9 . One of the components of such efficiency is the gain, which is the relationship between the head movement and the displacement of the eyes ${ }^{17}$. It is one of the values to be analyzed in the results obtained in the examination. It is calculated by dividing the speed of the head movement by the speed of the eye movement. Hence, values close to one indicate similar speeds.

Although the suggested normal values are those close to one, there is an evident need to know the reference values for the analysis of the VOR gain based on a range (minimum and maximum value) that enables a precise vestibular diagnosis. This is particularly so if other associated factors - e.g., age and brand of the equipment used - are considered. Moreover, the value close to one has been informed for the study of the lateral semicircular canal, but not for the anterior and posterior ones.

However, no review has yet grouped the existing studies on the theme, at the same time identifying a consensus between the various published articles. Therefore, the present integrative review aimed to identify and analyze the available evidence on the reference values for the vestibulo-ocular reflex gain, obtained with the video head impulse test.

\section{METHODS}

\section{Research strategy}

The research team conducted an integrative literature review on reference values for results analysis of the video head impulse test (VHIT). The paper was designed based on guidelines and orientations of the Preferred Reporting Items for Systematic Reviews (PRISMA) ${ }^{18,19}$. The first step in the research was to develop the research question for the literature review, which was defined as: "What are the reference values for vestibulo-ocular reflex gain obtained with the video head impulse test?". 
The review was based on a search for studies published in the ProQuest, EBSCO, PubMed, ScienceDirect, Cochrane Library, LILACS, and SciELO databases. Each researcher carried it out in October and November 2019 using combinations of the following descriptors, first in English and then in Spanish and Portuguese: "Normative values" and "video head impulse test", "Normative data" and "video head impulse test", "Normative findings" and "video head impulse test", "Reference values" and "video head impulse test". The descriptors were combined with the Boolean operator AND.

\section{Selection criteria}

The types of studies included in the search were original research and review articles (either systematic or meta-analysis). The inclusion criteria considered studies published from 2009 to the present, performed in humans. The exclusion criteria encompassed papers unrelated to the purpose and question of this research, those that included exam results of specific otologic pathologies (Ménière's disease, vestibular neuronitis, vestibular schwannoma), findings in other conditions unrelated to the vestibular system (e.g., bruises in athletes), comparisons between the results of the caloric test and that of Dix-Hallpike, duplicated studies between the databases, irrelevant studies, or those written in languages other than the predefined ones.

In the search, 10,250 potential articles were identified based on the abovementioned combination of descriptors and inclusion criteria. The process of analysis of the articles had three stages. The first one involved reading the titles and abstracts; hence, the clearly irrelevant articles were dismissed. In the second stage, the articles were read in full to verify whether they answered the research question, at the same time applying the exclusion criteria. Lastly, the third stage consisted of the critical analysis of the selected articles, following the Critical Appraisal of Diagnostic Evidence $(\mathrm{CADE})^{20}$. It was independently conducted by the assessors (H.S.P; P.O.D); in case they disagreed, a third assessor was invited (S.R.R) to solve the problem.

Of the 10,250 articles initially found in the databases, 20 were excluded for being duplicated in the search, and 10,219 , for being unrelated to the purpose and/or the question of the research. After reading in full the 14 articles evaluated for eligibility, 10 were selected for this review. The identification and characterization of the included articles are presented in Figure 1.

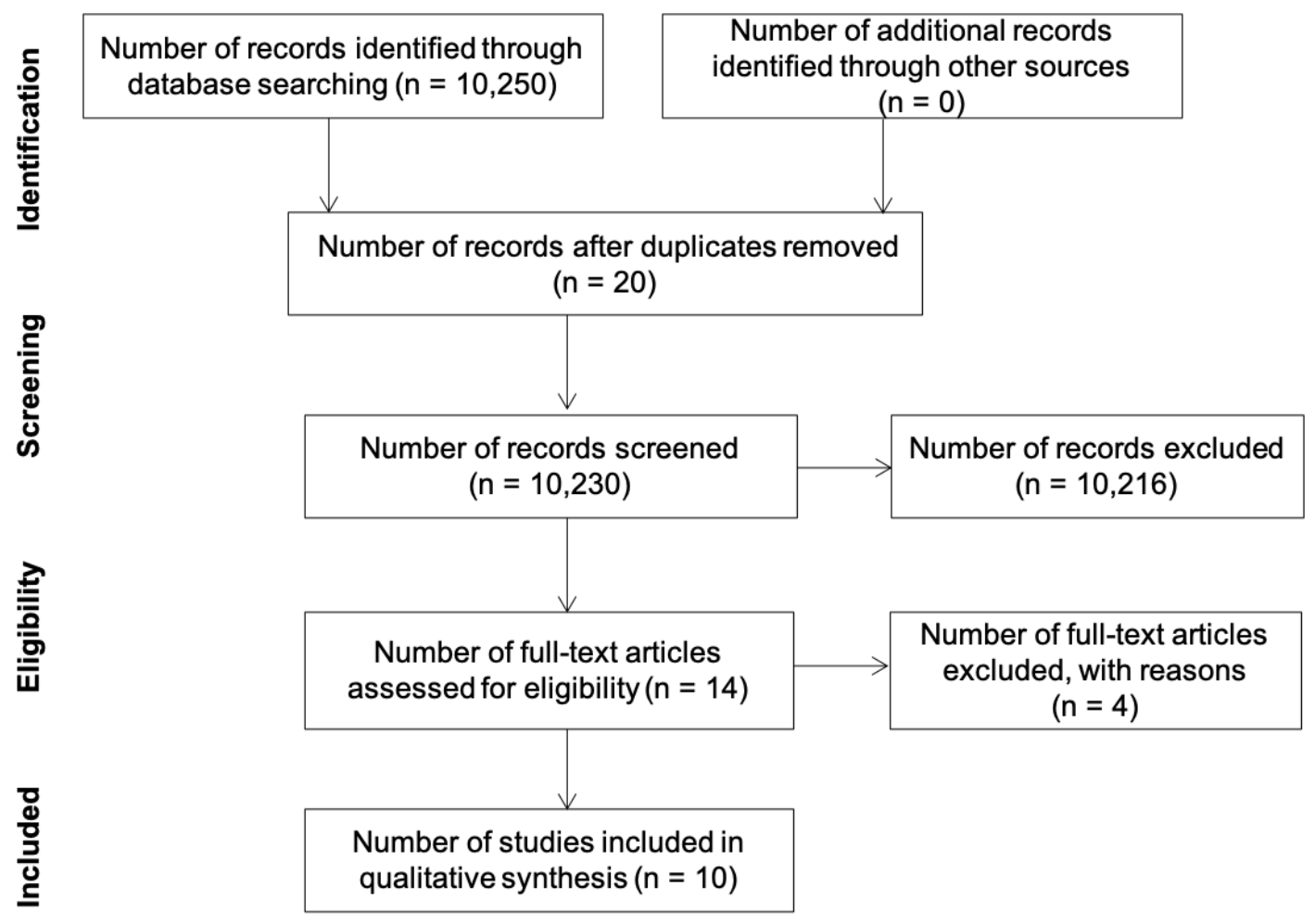

*Based on the Preferred Reporting Items for Systematic Reviews and Meta-analyses (PRISMA)

Figure 1. Flowchart with the selection of the articles. 


\section{LITERATURE REVIEW}

Based on the combination of descriptors in English, Spanish, and Portuguese, 10,250 potential articles were identified, of which 14 were selected after applying the inclusion and exclusion criteria, having already read the titles and/or abstracts. Four of these articles were dismissed after reading them in full. Hence, 10 articles, which are described in detail in Table 1, were included in the analysis. The results were presented considering the author, year, country, sample size (n), equipment used, planes assessed - horizontal, RALP (right anterior/left posterior), and LARP (left anterior/ right posterior) -, and main values obtained according to the ages assessed. Due to the heterogeneity of the equipment used, age ranges, and planes assessed, it was not possible to group the data based on statistical analysis. Thus, the present study is a systematic review without meta-analysis.

Table 1. Characteristics of the articles selected for the review

\begin{tabular}{|c|c|c|c|c|c|}
\hline $\begin{array}{c}\text { Author and } \\
\text { year }\end{array}$ & Country & Sample & Equipment used & $\begin{array}{c}\text { Planes } \\
\text { assessed }\end{array}$ & Main results \\
\hline $\begin{array}{l}\text { Mossman } \\
\text { et al. }(2015)^{21}\end{array}$ & $\begin{array}{c}\text { New } \\
\text { Zealand }\end{array}$ & $\begin{array}{c}60 \text { subjects aged } 20 \text { to } 80 \\
\text { years (10 participants per } \\
\text { decade). } \\
\text { Without brain disorders, } \\
\text { vertigo, or restricted neck } \\
\text { movement. }\end{array}$ & $\begin{array}{l}\text { EyeSeeCam, } \\
\text { Interacoustics }\end{array}$ & Horizontal & $\begin{array}{l}0.97 \text { in } 80 \mathrm{~ms} \\
0.94 \text { in } 60 \mathrm{~ms}\end{array}$ \\
\hline $\begin{array}{l}\text { Matiño- } \\
\text { Soler et al. } \\
(2015)^{22}\end{array}$ & Spain & $\begin{array}{l}212 \text { subjects aged } 6 \text { to } 95 \\
\text { years. } \\
\text { Without a history of auditory, } \\
\text { vestibular, visual, or } \\
\text { neurological changes. }\end{array}$ & $\begin{array}{c}\text { vHIT, } \\
\text { GN Otometrics. }\end{array}$ & Horizontal & $\begin{array}{c}\text { 6-10 years: } 1.04+/-0.06 \\
\text { 11-20 years: } 1.05+/-0.05 \\
\text { 21-30 years: } 1.05+/-0.05 \\
\text { 31-40 years: } 1.08+/-0.07 \\
\text { 41-50 years: } 1.08+/-0.07 \\
\text { 51-60 years: } 1.07+/-1.06 \\
\text { 61-70 years: } 1.07+/-0.08 \\
\text { 71-80 years: } 1.08+/-0.05 \\
\text { 81-90 years: } 1.09+/-0.10 \\
\text { 91 years or older: } 0.87+/-0.08 \\
\text { Total } 1.06+/-0.07 \\
\end{array}$ \\
\hline $\begin{array}{l}\text { McGarvie } \\
\text { et al. }(2015)^{23}\end{array}$ & Australia & $\begin{array}{l}91 \text { subjects aged } 10 \text { to } 89 \\
\text { years, grouped by decades. } \\
\text { Without a history of vestibular } \\
\text { changes. }\end{array}$ & $\begin{array}{c}\text { vHIT, } \\
\text { GN Otometrics. }\end{array}$ & $\begin{array}{l}\text { Horizontal } \\
\text { RALP } \\
\text { LARP }\end{array}$ & $\begin{array}{l}\text { Horizontal: Values close to } 1 \text { for all age ranges. } \\
\text { RALP and LARP: Values between } 0.8 \text { and } 1 . \\
\text { They tend to decrease as age increases. }\end{array}$ \\
\hline $\begin{array}{l}\text { Yang et al. } \\
(2016)^{24}\end{array}$ & Korea & $\begin{array}{l}\text { Without a history of auditory, } \\
\text { vestibular, or neurological } \\
\text { disorders, or postural or gait } \\
\text { anomalies. }\end{array}$ & $\begin{array}{l}\text { ICS Impulse, } \\
\text { GN Otometrics. }\end{array}$ & Horizontal & $\begin{array}{l}20 \text { years: } 1.01+/-0.06 \\
30 \text { years: } 1.01+/-0.54 \\
40 \text { years: } 1.00+/-0.77 \\
50 \text { years: } 1.03+/-0.06 \\
60 \text { years: } 1.04+/-0.08 \\
\text { Total: } 1.02+/-0.07\end{array}$ \\
\hline $\begin{array}{l}\text { Bansal et al. } \\
(2016)^{25}\end{array}$ & India & $\begin{array}{c}25 \text { young adults aged } 17 \text { to } 25 \\
\text { years. } \\
\text { Without a history of } \\
\text { neurological, auditory, } \\
\text { vestibular, neuromuscular, or } \\
\text { cervical changes, or excessive } \\
\text { noise exposure. }\end{array}$ & $\begin{array}{c}\text { vHIT, } \\
\text { GN Otometrics. }\end{array}$ & $\begin{array}{l}\text { Horizontal } \\
\text { RALP } \\
\text { LARP }\end{array}$ & $\begin{array}{l}\text { RA: } 0.88+/-0.10 ; \text { LP: } 0.82+/-0.07 \\
\text { LA: } 0.91+/-0.14 ; \text { RP: } 0.85+/-0.09\end{array}$ \\
\hline
\end{tabular}




\begin{tabular}{|c|c|c|c|c|c|}
\hline $\begin{array}{l}\text { Author and } \\
\text { year }\end{array}$ & Country & Sample & Equipment used & $\begin{array}{c}\text { Planes } \\
\text { assessed }\end{array}$ & Main results \\
\hline $\begin{array}{l}\text { Wiener et al. } \\
(2017)^{26}\end{array}$ & Germany & $\begin{array}{l}274 \text { children aged } 1 \text { to } 15 \\
\text { years, divided into } 15 \text { age } \\
\text { groups, and another group } \\
\text { comprising } 26 \text { adolescents and } \\
\text { adults aged } 16 \text { to } 67 \text { years. } \\
\text { Without a history of } \\
\text { neurological, vestibular, } \\
\text { ophthalmological, or } \\
\text { oculomotor disorders, or } \\
\text { any other potentially relevant } \\
\text { medical history. }\end{array}$ & $\begin{array}{l}\text { Ulmer, } \\
\text { Synapsys. }\end{array}$ & Horizontal & $\begin{array}{l}\text { Horizontal, anterior, and posterior, respectively } \\
\qquad \begin{array}{c}\text { 1: } 090,0.95,0.87 \\
\text { 2: } 0.88,0.95,0.89 \\
\text { 3: } 0.91,0.95,0.93 \\
\text { 4: } 0.95,0.98,0.96 \\
\text { 5: } 0.95,0.97,0.96 \\
\text { 6: } 0.96,0.98,0.94 \\
\text { 7: } 0.97,0.98,0.96 \\
\text { 8: } 0.98,1.02,0.98 \\
\text { 9: } 0.98,1.00,0.98 \\
10: 0.98,0.99,0.98 \\
11: 1.01,1.00,1.00 \\
12: 0.99,1.02,0.99 \\
13: 1.00,1.02,1.03 \\
14: 1.01,1.03,1.02 \\
15: 1.02,1.02,0.99 \\
\text { Adults: } 1.02,1.03,0.99\end{array}\end{array}$ \\
\hline $\begin{array}{l}\text { Lehnen et al. } \\
\qquad(2017)^{27}\end{array}$ & Germany & $\begin{array}{l}44 \text { children aged } 4 \text { to } 18 \text { years, } \\
\text { divided into three groups: early } \\
\text { childhood (4-7 years), middle } \\
\text { childhood (8-11 years), and } \\
\text { adolescence ( } 12-18 \text { years). } \\
\text { Without a history of vestibular } \\
\text { disorders. }\end{array}$ & $\begin{array}{l}\text { EyeSeeCam, } \\
\text { Interacoustics. }\end{array}$ & Horizontal & $\begin{array}{c}4 \text { to } 7 \text { years: } 0.96+/-0.07 \\
8 \text { to } 11 \text { years: } 0.95+/-0.06 \\
12 \text { to } 18 \text { years: } 0.94+/-0.07\end{array}$ \\
\hline $\begin{array}{l}\text { Wenzel et al. } \\
(2017)^{28}\end{array}$ & Germany & $\begin{array}{l}\text { Without a history of auditory, } \\
\text { or vestibular disorders, though } \\
\text { initially tracked to clarify any } \\
\text { possible auditory disorder. }\end{array}$ & $\begin{array}{l}\text { EyeSeeCam, } \\
\text { Interacoustics. }\end{array}$ & Horizontal & $\begin{array}{l}1.06+/-0.25 \text { in } 40 \mathrm{~ms} . \\
0.76+/-0.21 \text { in } 60 \mathrm{~ms} . \\
0.53+/-0.21 \text { in } 80 \mathrm{~ms} .\end{array}$ \\
\hline \multirow[t]{2}{*}{$\begin{array}{l}\text { Bachmann et } \\
\text { al. }(2018)^{29}\end{array}$} & \multirow[t]{2}{*}{$\begin{array}{l}\text { United } \\
\text { States }\end{array}$} & $\begin{array}{l}30 \text { children aged } 4 \text { to } 12 \text { years, } \\
\text { equally divided into three } \\
\text { groups: } 4-6 \text { years, } 7-9 \text { years, } \\
\text { and } 10-12 \text { years. } \\
11 \text { adults (control group). }\end{array}$ & $\begin{array}{l}\text { ICS Impulse, } \\
\text { GN Otometrics. }\end{array}$ & Horizontal & $\begin{array}{c}\text { Horizontal: } \\
\text { R: } 1.04+/-0.09 ; \text { L: } 0.96+/-0.09 \\
\text { RA } 0.90+/-0.19 ; \text { LP } 0.91+/-0.14\end{array}$ \\
\hline & & $\begin{array}{l}\text { Without a history of vestibular } \\
\text { disorders. }\end{array}$ & & LARP & LA $0.80+/-0.11 ;$ RP $0.95+/-0.09$ \\
\hline $\begin{array}{l}\text { Lee et al. } \\
(2018)^{30}\end{array}$ & Korea & $\begin{array}{l}\text { Without a history of auditory, } \\
\text { vestibular, or neurological } \\
\text { disorders, or postural or gait } \\
\text { anomalies. }\end{array}$ & $\begin{array}{l}\text { A: ICS Impulse, } \\
\text { GN Otometrics. }\end{array}$ & Horizontal & $\begin{array}{l}A: 1.05+/-0.07 \\
B: 0.95+/-0.05\end{array}$ \\
\hline
\end{tabular}

LARP: left anterior, right posterior / RALP: right anterior, left posterior / R: right / L: left. 
The articles analyzed were collected mostly from the PubMed database, followed by EBSCO and ProQuest. The ScienceDirect, LILACS, SciELO, and Cochrane Library databases did not return relevant results with the descriptors used. Regarding the year of publication, although the present research included articles since 2009 , the analyzed ones were published only recently, between 2015 and 2018 - i.e., approximately one decade after the vHIT was introduced as a vestibular function assessment procedure. The countries of origin that stood out are European (Germany ${ }^{26-28}$ and Spain ${ }^{22}$ ), followed by Korea ${ }^{24,30}$, Australia ${ }^{23}$, New Zealand ${ }^{21}$, India ${ }^{25}$, and the United States ${ }^{29}$. On the other hand, the appreciation did not include any Latin American studies, demonstrating the need for local data.

The age groups studied in the analyzed articles are heterogeneous. Four of them focused mainly on the child and /or youth population ${ }^{26-29}$; three pieces of research involved young adults and/or adults ${ }^{24,25,30}$; none of them included exclusively older adults; and three considered a combination of all these age groups $^{21-23}$. It should be mentioned that all the studies analyzed included men and women. Regarding the sample size, two studies counted with 274 and 212 subjects $^{22,26}$. Three other studies included from 50 to 91 participants ${ }^{21,23,24}$. Lastly, five authors included 6 to 44 subjects $^{25-30}$. The quite small samples used in some articles call attention, especially considering the broad age range - which diminishes the validity of the conclusions proposed by the authors. Hence, it is suggested that a greater number of participants be included to obtain data representative of the population, allowing for a reliable statistical analysis.

Concerning the assessed planes, four articles obtained gain values for vestibulo-ocular reflex on the horizontal, RALP, and LARP planes ${ }^{23,25,26,29}$, while six studies only obtained them on the horizontal plane $21,22,24,27,28,30$. On the horizontal plane, the reference values range from 0.80 to 1.06 , while on the RALP and LARP planes, the values range from 0.80 to 1.03 . Only one study (which worked with six children aged five to 36 months) reports values lower than $0.80^{28}$ on the horizontal plane. It was noted that the gain slightly decreases both as the age increases and as the vertical SCCs are studied. Hence, it is proposed that all planes (horizontal, RALP, and LARP) be evaluated to establish a complete reference in relation to the various age ranges.

In six of the analyzed studies, the said planes were assessed using VHIT equipment manufactured by
Otometrics (Denmark), followed by two that employed equipment manufactured by Interacoustics (Denmark), one, by Synapsys (France), and one, by SLMed (Korea). It is highlighted that the emphasis of the studies conducted with Otometrics addresses the analysis on the horizontal, RALP, and LARP planes, in a broad age range, from 4 to 95 years. On the other hand, the research with Interacoustics considered only obtaining data from the assessment on the horizontal plane in the child population in one study, and in 60 subjects 20 to 80 years old, grouped by decades in equal numbers. In the case of data obtained with Synapsys and SLMed, all the planes were assessed in 274 children aged one to 15 years in the first case, and only the horizontal plane in a small sample of young adults. Although various brands in the market developed equipment to assess this function, not all of them have reference values for all the planes assessed in the examination, or for the different age ranges. This need is emphasized by Lee et al. $(2018)^{30}$, after showing differences in the VHIT gains in normal subjects depending on the device and analysis method used (Impulse by GN Otometrics versus SLVNG by SLMED Inc.).

Other relevant gain-related data in the selected articles were analyzed, approaching the number of impulses, the assessor's experience, the patient's distance to the object, and the percentage of asymmetry between the ears. Concerning the number of head impulses, the results are heterogeneous, describing at least five ${ }^{21,26}, 10^{23,24,30}, 15^{28}$, or $20^{22,25,29}$ valid impulses on each side or for each canal studied. Also, six of the reviewed articles ${ }^{21,24,26,28-30}$ indicate that the assessor was trained and experienced to perform the examination, whereas the other articles do not mention this aspect. As for the patient's distance to the object, most kept one meter, with exceptions for 1.30 meters $^{26}, 1.5$ meters $^{21,28}$, and even 1.80 meters $^{23}$. Lastly, regarding the percentage of asymmetry between the ears, great variability was again noticed between the four pieces of research that touch the subject, ranging from $2 \%$ to $15 \%^{21,22,24,26}$.

The articles included in the review were analyzed regarding their methodological quality based on the Critical Appraisal of Diagnostic Evidence (CADE) $)^{20}$ (Table 2), although some items had to be adapted or dismissed because they did not fit the needs of this review. In summary, the great majority of the studies present at least a good quality level. Three articles ${ }^{21,23,26}$ included their findings' confidence intervals, which reinforces the quality of their analyses. Almost all the 
Table 2. Qualitative analysis of the included articles, following the Critical Appraisal of Diagnostic Evidence (CADE)

\begin{tabular}{|c|c|c|c|c|c|}
\hline & $\begin{array}{l}\text { Bachmann } \\
\text { et al., (2018) }\end{array}$ & $\begin{array}{l}\text { Wiener-Vacher } \\
\text { et al., (2017) }\end{array}$ & $\begin{array}{l}\text { Yang et al., } \\
\text { (2015) }\end{array}$ & $\begin{array}{l}\text { McGarvie } \\
\text { et al., (2015) }\end{array}$ & $\begin{array}{l}\text { Mossman } \\
\text { et al., (2015) }\end{array}$ \\
\hline $\begin{array}{l}\text { 1. Was there a plausible rationale for the } \\
\text { study? }\end{array}$ & Yes & Yes & Yes & Yes & Yes \\
\hline $\begin{array}{l}\text { 2. Was the index measure compared to a } \\
\text { reference standard? }\end{array}$ & Yes & No & No & No & No \\
\hline $\begin{array}{l}\text { 3. Were measures and procedures described } \\
\text { clearly? }\end{array}$ & Yes & Yes & Yes & Yes & Yes \\
\hline 4. Were measures administered independently? & Yes & NR & NR & NR & NR \\
\hline 5. Were measures administered with blinding? & No & No & No & No & No \\
\hline $\begin{array}{l}\text { 6. Were methods and participants specified } \\
\text { prospectively? }\end{array}$ & Yes & Yes & Yes & Yes & Yes \\
\hline $\begin{array}{l}\text { 7. Were participants recognizable and } \\
\text { representative of the actual diagnostic task? }\end{array}$ & Yes & Yes & Yes & Yes & Yes \\
\hline $\begin{array}{l}\text { 8. Were the reference standard and the index } \\
\text { test both administered to all participants? }\end{array}$ & Yes & No & No & No & No \\
\hline 9. Was $L R+$ (sensitivity/1-specificity) $\geq 10.0$ ? & NR & NR & NR & NR & NR \\
\hline 10. Was LR- (1-sensitivity/specificity) $\leq 0.10$ ? & NR & NR & NR & NR & NR \\
\hline \multirow{2}{*}{ 11. Was precision adequate? } & NR & Yes & NR & Yes & Yes \\
\hline & $\begin{array}{l}\text { Matiño-Soler } \\
\text { et al., (2015) }\end{array}$ & $\begin{array}{l}\text { Wenzel et al., } \\
\quad(2017)\end{array}$ & $\begin{array}{l}\text { Lee et al., } \\
\text { (2018) }\end{array}$ & $\begin{array}{l}\text { Bansal et al., } \\
\text { (2016) }\end{array}$ & $\begin{array}{l}\text { Lehnen et al., } \\
\text { (2017) }\end{array}$ \\
\hline $\begin{array}{l}\text { 1. Was there a plausible rationale for the } \\
\text { study? }\end{array}$ & Yes & Yes & Yes & Yes & Yes \\
\hline $\begin{array}{l}\text { 2. Was the index measure compared to a } \\
\text { reference standard? }\end{array}$ & No & No & No & No & No \\
\hline $\begin{array}{l}\text { 3. Were measures and procedures described } \\
\text { clearly? }\end{array}$ & Yes & Yes & Yes & Yes & Yes \\
\hline 4. Were measures administered independently? & NR & NR & NR & NR & NR \\
\hline 5. Were measures administered with blinding? & No & No & No & No & No \\
\hline $\begin{array}{l}\text { 6. Were methods and participants specified } \\
\text { prospectively? }\end{array}$ & Yes & Yes & Yes & Yes & No \\
\hline $\begin{array}{l}\text { 7. Were participants recognizable and } \\
\text { representative of the actual diagnostic task? }\end{array}$ & Yes & Yes & Yes & Yes & No \\
\hline $\begin{array}{l}\text { 8. Were the reference standard and the index } \\
\text { test both administered to all participants? }\end{array}$ & No & No & No & No & No \\
\hline 9. Was LR+ (sensitivity/1-specificity) $\geq 10.0$ ? & NR & NR & NR & NR & NR \\
\hline 10. Was LR- (1-sensitivity/specificity) $\leq 0.10$ ? & NR & NR & NR & NR & NR \\
\hline 11. Was precision adequate? & NR & NR & NR & NR & NR \\
\hline
\end{tabular}

NR: Not reported

Adapted from Dollaghan, $(2007)^{20}$

studies precisely describe the participants, as well as the methods employed. None of the studies included in this research considered either the positive or the negative likelihood ratio because the original studies did not compare participants with pathologies.

Regarding the said good quality level of the articles, the author of $\mathrm{CADE}^{20}$ explains that the evidence is compelling when there are few weak or questionable points in the study. The second level is the suggestive category, in which there are questionable points regarding the validity of the studies. Lastly is the equivocal category, in which there are more questionable points than solid ones in the research. The clinical decisions should be aligned with this when adopting new clinical techniques.

\section{CONCLUSION}

The present study points out that there is little scientific evidence addressing the normative values for vestibulo-ocular reflex gain obtained with the video 
head impulse test. The research on the theme has only recently been developed and published, starting in 2015, mostly in European countries, followed by others in different parts of the world. However, Latin American countries still lack references on the subject, which shows the need for a greater number of studies, including normative values to strengthen the scientific evidence.

Altogether, 10 articles were identified and analyzed, which suggest reference values for VOR gain close to one. Specifically, on the horizontal plane, the values ranged from 0.80 to 1.06 , while on the RALP and LARP planes they ranged from 0.80 to 1.03 . Some differences were noted regarding age and the comparison between vertical and horizontal canals. This points to research that can result in a systematic review with meta-analysis, to make a quantitative analysis of the different variables that can influence the vHIT-measured VOR gain.

The importance of having normative values available lies in their being a reference guide for future comparison with values obtained in the clinical practice. These are essential to medical decision-making regarding the diagnosis, treatment, and follow-up of the health condition of a given population.

\section{REFERENCES}

1. Álvarez-Santacruz C, López-Robles M, Hellín Meseguer D. Experiencia con video head impulse testing (v-Hit). Rev. ORL. 2017;8(1):5-15.

2. Lévêque $M$, Seidermann $L$, Ulmer $E$, Chays $A$. Physiologie vestibulaire: bases anatomiques, cellulaires, immunohistochimiques et électrophysiologiques. Otorhinolaryngologie. Paris: Elsevier Masson; 2009.

3. Suárez C. Morfología y función del sistema Vestibular. En: Ramírez Camacho R (ed). Trastornos del equilibrio. Madrid: Mc Graw-Hill Interamericana; 2003. p.3-19.

4. Binetti A. Fisiología vestibular. Revista Faso. 2015;22(1):14-21.

5. Herdman S, Clendaniel R. Vestibular rehabilitation. Fourth edition. Philadelphia: F. A Davis Company; 2014.

6. Riveros $\mathrm{H}$, Cohen $\mathrm{M}$, Badía $\mathrm{P}$, Anabalón J, Correa C. Utilidad de la prueba calórica mínima. Rev. Otorrinolaringol. Cir. Cabeza Cuello. 2005;65(3):193-6.
7. Redondo-Martínez J, Bécares-Martínez C, Orts-Alborch M, García-Callejo F, Pérez-Carbonell T, Marco-Algarra J. Relationship between Video Head Impulse Test (VHIT) and caloric test in patients with vestibular neuritis. Acta Otorrinolaringol Esp. 2016;67(3):156-61.

8. Boleas-Aguirre M, Migliaccio A, Carey J. Registro del reflejo vestibulooculomotor con la técnica de la bobina corneal en campo magnético (scleral search coil). Revisión de afecciones vestibulares periférica. Acta Otorrinolaringol Esp. 2007;58(7):321-6.

9. Carriel P, Rojas M. Prueba de impulso cefálico: bases fisiológicas y métodos de registro del reflejo vestíbulo oculomotor. Rev. Otorrinolaringol. Cir. Cabeza Cuello. 2013;73(2):206-12.

10. Pérez-Fernández N, Gallegos-Constantino V, Barona-Lleo L, Manríque-Huarte R. Exploración clínica y videoasistida del reflejo vestíbulooculomotor: Análisis comparativo. Acta Otorrinolaringol Esp. 2012;63(6):429-35.

11. Ulmer E, Chays A. Head Impulse Test de Curthoys \& Halmagyi. Un dispositif d'analyse. Ann Otolaryngol Chir Cervicofac. 2005;122(2):84-90.

12. MacDougall HG, Weber KP, McGarvie LA, Halmagyi GM, Curthoys IS. The video head impulse test. Diagnostic accuracy in peripheral vestibulopathy. Neurology. 2009;73(14):1134-41.

13. Gómez A, Bruna A, Franzoy D, Julio M, Olivares R, Vicencio N. Eficiencia del reflejo vestíbulo ocular mediante la aplicación de la prueba Video Head Impulse Test, en estudiantes de primer año de las Escuelas de Fonoaudiología y de Tecnología Médica de la Universidad de Valparaíso. Rev. Otorrinolaringol. Cir. Cabeza Cuello. 2015;75(2):137-44.

14. Silva M, Arias R, Carriel C, Sariego H. Evaluación del Video Head Impulse Test (V-Hit) en el diagnóstico del neurinoma del acústico. Rev. Otorrinolaringol. Cir. Cabeza Cuello. 2015;75(3):213-9.

15. Halmagyi GM, Weber KP, Aw ST, Todd MJ, Curthoys IS. Impulsive testing of semicircular canal function. In: Kennard C, Leigh RJ (eds). Using eye movements as an experimental probe of brain function. London: Elsevier Science; 2008. p.187-94.

16. Halmagyi M, Curthoys I. The Video Head Impulse Test in clinical practice. Neurol Sci Neurophysiol. NSN. 2018;35(1):1-5.

17. Alhabib S, Saliba I. Video Head Impulse Test: a review of the literature. Eur Arch Otorhinolaryngol. 2017;274(3):1215-22. 
18. Moher D, Liberati A, Tetzlaff J, Altman D, PRISMA Group. Preferred Reporting Items for Systematic Reviews and Meta-Analyses: The PRISMA Statement. Guidelines and Guidance. PLoS Med. 2009;6(7):1-7.

19. Liberati A, Altman D, Tetzlaff J, Mulrow C, Gotzsche $P$, loannidis $J$ et al. The PRISMA statement for reporting systematic reviews and meta-analyses of studies that evaluate health care interventions: explanation and elaboration. Guidelines and Guidance. PLoS Med. 2009;6(7):1-28.

20. Dollaghan CA. The handbook for evidence-based practice in communication disorders. Baltimore: Paul H Brookes Publishing; 2007.

21. Mossman B, Mossman S, Purdie G, Schneider E. Age dependent normal horizontal VOR gain of head impulse test as measured with video-oculography. J Otolaryngol Head Neck Surg. 2015;44(29):1-8.

22. Matiño-Soler E, Esteller-More E, Martin-Sanchez J, Martinez-Sanchez J, Perez-Fernandez N. Normative data on angular vestibulo-ocular responses in the yaw axis measured using the Video Head Impulse Test. Otol Neurotol. 2015;36(3):466-71.

23. McGarvey L, MacDougall M, Malmagyi G, Burgess A, Weber K, Curthoys I. The Video Head Impulse Test (VHIT) of semicircular canal function-agedependent normative values of VOR gain in healthy subjects. Front. Neurol. 2015;6(154):1-11.

24. Yang CJ, Lee JY, Kang BC, Lee HS, Yoo MH, Park HJ. Quantitative analysis of gains and catch-up saccades of video-head-impulse testing by age in normal subjects. Clin Otolaryngol. 2016;41(5):1-7.

25. Bansal S, Kumar S. Assessment of VOR gain function and its test-retest reliability in normal hearing individuals. Eur Arch Otorhinolaryngol. 2016;273(10):3167-73.

26. Wiener-Vacher S, Wiener S. Video Head Impulse Tests with a remote camera system: normative values of semicircular canal vestibulo-ocular reflex gain in infants and children. Front. Neurol. 2017;8(434):1-14.

27. Lehnen N, Ramaioli C, Sean N, Bartl K, Kohlbecher $\mathrm{S}$, Jahn $\mathrm{K}$ et al. Clinical and video head impulses: a simple bedside test in children. $J$ neurol. 2017;264(5):1002-4.

28. Wenzel A, Eck S, Hülse K, Rohr K, Hörmann K, Umbreit $C$ et al. Development of a new software and test setup for analyzing hVOR in very young children by VHIT. Journal of Vestibular Research. 2017;27(2-3):155-62.
29. Bachmann K, Sipos K, Lavender V, Hunter L. Video Head Impulse Testing in a pediatric population: normative findings. J Am Acad Audiol. 2018;29(5):417-26.

30. Lee S, Yoo M, Park J, Kang B, Yang C, Kang W et al. Comparison of Video Head Impulse Test (vHIT) gains between two commercially available devices and by different gain analytical methods. Otol Neurotol. 2018;39(5):297-300. 